\title{
Interference of a Commercial Catalase preparation in Laccase and Peroxidase Activities
}

\author{
Nara Ballaminut ${ }^{1}$, Renata Yamanaka ${ }^{2}$ and Katia Maria Gomes Machado ${ }^{2 *}$ \\ ${ }^{1}$ Instituto de Botânica; Secretaria do Meio Ambiente do Estado, São Paulo - SP - Brasil. ${ }^{2}$ Universidade Católica \\ de Santos, Santos - SP - Brasil
}

\begin{abstract}
The influence of commercial catalase preparations (fungal and bovine origin) on laccase and peroxidase activity assays was evaluated using enzymatic extracts obtained from several basidiomycetes grown under different culture conditions. No hydrogen peroxide was detected in the extracts. Inhibition of laccase activity by 40 to $80 \%$ was related to the catalase source. In addition, oxidation of the substrate (ABTS) by fungal catalase in the absence of the enzymatic extract from basidiomycetes was observed. The results demonstrated the need for the evaluation of interference of the commercial catalase preparation when its use was required in the reaction mixture.
\end{abstract}

Key words: Peroxidase, fungi, basidiomycetes, hydrogen peroxide, enzymatic inhibition

\section{INTRODUCTION}

The study of the extracellular ligninolytic activity of basidiomycetes started in the 1930s, but lignin peroxidase (E.C. 1.11.1.14), an enzyme which is able to degrade phenolic and non-phenolic compounds in the presence of hydrogen peroxide $\left(\mathrm{H}_{2} \mathrm{O}_{2}\right)$, was only discovered in 1983 (Tien and Kirk, 1983; Glenn et al., 1983). A new manganesedependent peroxidase (E.C. 1.11.1.13) was described in 1984 (Kuwarara et al., 1984).

Laccase (E.C. 1.10.3.2), a copper-containing polyphenoloxidase, has been considered to be an integrating part of the ligninolytic enzymatic system of basidiomycetes (Claus 2004; Baldrian 2005). Known for its capacity to catalyze the reduction of molecular oxygen to water, with the concomitant oxidation of phenolic and polyphenolic substrates in the absence of the formation of $\mathrm{H}_{2} \mathrm{O}_{2}$, this enzyme became more important when its ability to degrade non-phenolic substructures of lignin in the presence of mediating substances was demonstrated (Bourbonnais and Paice, 1988).

The determination of laccase activity in crude extracts from basidiomycete fungi requires a series of precautions because the capacity of $\mathrm{H}_{2} \mathrm{O}_{2}$ production is common in this group of fungi (Moreira et al. 1998; Böckle et al., 1999; Guillén et al. 2002; Srebotnik and Boisson 2005). Thus, catalase is usually added to guarantee the complete absence of $\mathrm{H}_{2} \mathrm{O}_{2}$ in the reaction medium (Srinivasan et al., 1995; Lonergan and Baker 1995; Mayer and Staples, 2002; Gonzales et al. 2002).

Previous studies conducted have indicated the influence of fungal catalase on the laccase assay. In an attempt to standardize the method for the determination of laccase activity, the present study evaluated i) the influence of commercial catalase

\footnotetext{
* Author for correspondence: katia@ unisantos.br
} 
preparations of fungal and bovine origins on laccase and peroxidase activityies assays, and ii) the influence of $\mathrm{pH}$ on the oxidation of ABTS by the fungal catalase preparation. For this, enzymatic extracts obtained from several basidiomycetes grown under different culture conditions (basal liquid medium, solid substrate consisting of sawdust or sugarcane bagasse) were used.

\section{MATERIAL AND METHODS}

\section{Fungi/enzymes}

Psilocybe castanella CCB444, Lentinus crinitus CCB274 and Trametes villosa CCB176 obtained from the Basidiomycete Culture Collection (CCB), Instituto de Botânica, São Paulo, were maintained on $2 \%$ malt extract agar (MEA) at $4^{\circ} \mathrm{C}$. Horseradish peroxidase and sawdust colonized with Pleurotus ostreatus were provided by Toyobo do Brasil S.A. Commercial catalase preparations of bovine (Sigma, C-1345) and Aspergillus niger origins (ICN Biomedicals Inc, 9001-05-2) were used. Laccase from Rhus vernicifera (Sigma) was used as reference.

\section{Growth on solid substrate}

Five MEA discs of $P$. castanella and $L$. crinitus measuring $5 \mathrm{~mm}$ in diameter were used to inoculate $100 \mathrm{~g}$ of solid sterilized substrate $\left(121^{\circ} \mathrm{C}\right)$. The substrate was sugarcane bagasse and soy flour $(\mathrm{C}: \mathrm{N}$ ratio $=90)$. The substrate humidity was kept close to $70 \%$. The fermentation was carried out in triplicate and the incubation was maintained at $28^{\circ} \mathrm{C}$.

\section{Growth in liquid medium}

T. villosa was previously grown on $2 \%$ MEA at $28^{\circ} \mathrm{C}$ until the mycelium occupied $3 / 4$ of the medium surface. Two fungal discs measuring 5 $\mathrm{mm}$ in diameter were removed to inoculate 250 $\mathrm{mL}$ flasks containing $50 \mathrm{~mL}$ basal medium (Kirk et al., 1976, modified). The final composition of the medium (in $1 \mathrm{~L}$ ) was as follows: $5 \mathrm{~g}$ glucose, $1 \mathrm{~mL}$ thiamine $\mathrm{HCl}, 0.2298 \mathrm{~g}$ ammonium tartrate, $0.2 \mathrm{~g}$ $\mathrm{KH}_{2} \mathrm{PO}_{4}, \quad 0.05 \quad \mathrm{~g} \quad \mathrm{MgSO}_{4} .7 \mathrm{H}_{2} \mathrm{O}, \quad 0.013 \mathrm{~g}$ $\mathrm{CaCl}_{2} \cdot 2 \mathrm{H}_{2} \mathrm{O}, 0.016 \mathrm{~g} \mathrm{MnSO}_{4} \cdot \mathrm{H}_{2} \mathrm{O}, 1 \mathrm{~mL}$ mineral solution $\left(3 \mathrm{~g} \mathrm{MgSO}_{4}, 1 \mathrm{~g} \mathrm{NaCl}, 100 \mathrm{mg}\right.$ $\mathrm{FeSO}_{4} \cdot 7 \mathrm{H}_{2} \mathrm{O}, 100 \mathrm{mg} \mathrm{CoSO}{ }_{4} \cdot \mathrm{H}_{2} \mathrm{O}, 82 \mathrm{mg} \mathrm{CaC}$, $100 \mathrm{mg} \mathrm{ZnSO}$, $10 \mathrm{mg} \mathrm{CuSO}_{4} .5 \mathrm{H}_{2} \mathrm{O}, 10 \mathrm{mg}$ $\left.\left.\mathrm{AlK}\left(\mathrm{SO}_{4}\right)_{2}, 10 \mathrm{mg} \mathrm{H}_{3} \mathrm{BO}_{3}, 10 \mathrm{mg} \mathrm{NaMoO}\right)_{4}\right), 0.5$ $\mathrm{mL}$ vitamin supplement $(2 \mathrm{mg}$ biotin, $2 \mathrm{mg}$ folic acid, $5 \mathrm{mg}$ thiamine $\mathrm{HCl}, 10 \mathrm{mg}$ pyridoxine, $5 \mathrm{mg}$ nicotinic acid), and $10 \mathrm{~mL} 50 \mathrm{mM}$ sodium acetate buffer, $\mathrm{pH}$ 4.7. The content of the flasks was filtered at different time intervals and the extract was used for the determination of enzymatic activity. The tests were carried out in triplicate.

\section{Enzyme extraction}

\section{Solid cultures}

At given time intervals, $100 \mathrm{~g}$ of the flask content was extracted with $50 \mathrm{mM}$ sodium acetate buffer, $\mathrm{pH} 4.5$, at a proportion of 1:3(w/v). The mixture was homogenized manually ( $3 \mathrm{~min}$ ), followed by shaking at $120 \mathrm{rpm}$ for one hour and manual stirring for $3 \mathrm{~min}$. The filtrate was centrifuged at $10,000 \mathrm{rpm}$ for $10 \mathrm{~min}$ and supernatant was stored to more enzymatic assays.

\section{Liquid cultures}

At given time intervals, the content of the flasks was filtered through filter paper and the biomass was determined as dry weight $\left(60^{\circ} \mathrm{C}\right.$ for $\left.24 \mathrm{~h}\right)$. The filtrate was used for the determination of enzymatic activities.

\section{Determination of $\mathrm{H}_{2} \mathrm{O}_{2}$}

The presence of $\mathrm{H}_{2} \mathrm{O}_{2}$ in the enzymatic extract was determined using horseradish peroxidase (Moreira et al., 1998).

\section{Enzymatic activities}

Total oxidation of ABTS

The reaction mixture contained (in $1 \mathrm{~mL}$ ) $0.25 \mathrm{~mL}$ $50 \mathrm{mM}$ citrate-phosphate buffer, $\mathrm{pH} 4.0,0.1 \mathrm{~mL} 5$ $\mathrm{mM}$ ABTS, $0.6 \mathrm{~mL}$ of the enzymatic extract, and $0.05 \mathrm{~mL} 2 \mathrm{mM} \mathrm{H} \mathrm{H}_{2} \mathrm{O}_{2}$. Enzymatic kinetics was assayed by absorbance at $420 \mathrm{~nm}$ for $10 \mathrm{~min}$. One unit of enzymatic activity was defined as the amount of enzyme necessary to oxidize $1 \mu \mathrm{mol}$ of substrate per liter per minute (Machado and Matheus 2006).

\section{Laccase activity}

Laccase activity was determined as described for total oxidation of ABTS in the absence of $\mathrm{H}_{2} \mathrm{O}_{2}$ (Machado and Matheus 2006) or using the enzymatic extract preincubated for $10 \mathrm{~min}$ with $0.05 \mathrm{~mL}$ of fungal or bovine commercial catalase.

\section{Peroxidase activity}

Peroxidase activity was calculated as the difference between the values obtained for total ABTS oxidation and laccase activity (Eggert et al., 1996). 
Effect of reaction $\mathrm{pH}$ on ligninolytic activities

The effect of $\mathrm{pH}$ on ABTS oxidation by the commercial catalase preparation was therefore evaluated using $50 \mathrm{mM}$ citrate-phosphate buffers (pH 2.78, 3.80, 4.78 and 6.90) and $50 \mathrm{mM}$ sodium acetate buffer ( $\mathrm{pH} 4.50)$.

\section{RESULTS AND DISCUSSION}

Laccase activity of the enzymatic extracts obtained from $P$. castanella and $P$. ostreatus grown on solid substrate was inhibited by $80 \%$ in the presence of the fungal catalase preparation (Fig. 1). The laccase activity of Rhus vernicifera, used as a reference, was also inhibited (37\%). In addition, the evaluation of $P$. castanella's peroxidase activity yielded overestimated results in the presence of fungal catalase (113 U/L). No $\mathrm{H}_{2} \mathrm{O}_{2}$ was detected in the enzymatic extracts from $P$. castanella and $P$. ostreatus, confirming that the oxidation of ABTS, in the absence of catalase, was only due to the action of laccase. Also, no $\mathrm{H}_{2} \mathrm{O}_{2}$ was detected in the enzymatic extracts of $T$. villosa grown in liquid synthetic medium; however, the presence of fungal catalase inhibited laccase activity (Fig. 2).
Recently, Rescigno et al. (2007) evaluating several commercial preparations of tyrosinase as regards to their composition and purity, detected enzyme activities different from tyrosinase. The authors showed that the presence of enzymes other than tyrosine could lead to misinterpretation of results ascribed to tyrosinase activity under certain experimental conditions. Probably, the commercial catalase employed in the present study contained other enzymes, Aspergillus produced oxiredutases (laccase alike) and many other forms of catalase, including catalase with similar behavior to laccase (Navarro and Aguirre 1998).

The inhibition caused by the catalase preparation varied according to the time of the fungus cultures (Fig. 2) and was more pronounced at 17, 21 and 26 days (inhibition of laccase activity of 43, 75 and $84 \%$, respectively). No inhibition was observed at 31 days. This could indicate the production of laccase isoenzymes by $T$. villosa as reported about other basidiomycetes (Bonnarmet and Jeffries, 1990; Hakala et al., 2005). Probably, at 31 days the produced isoenzymes pattern suffered fewer influence by contaminants of fungal catalase preparation.

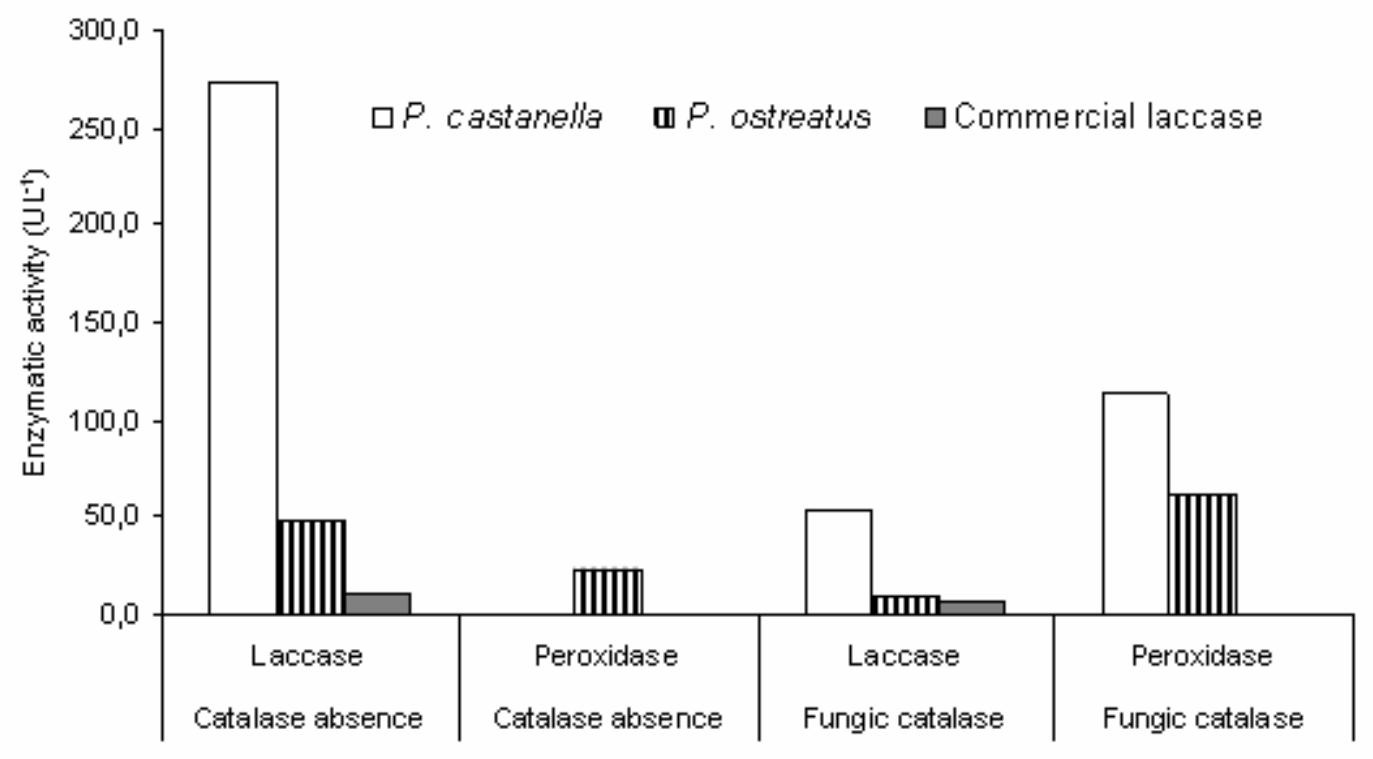

Figure 1 - Activities of laccase and peroxidases produced by Psilocybe castanella and Pleurotus ostreatus during growth on solid substrate determined in the absence and presence of a fungal commercial catalase preparation. Commercial laccase from Rhus vernicifera was used as reference. 


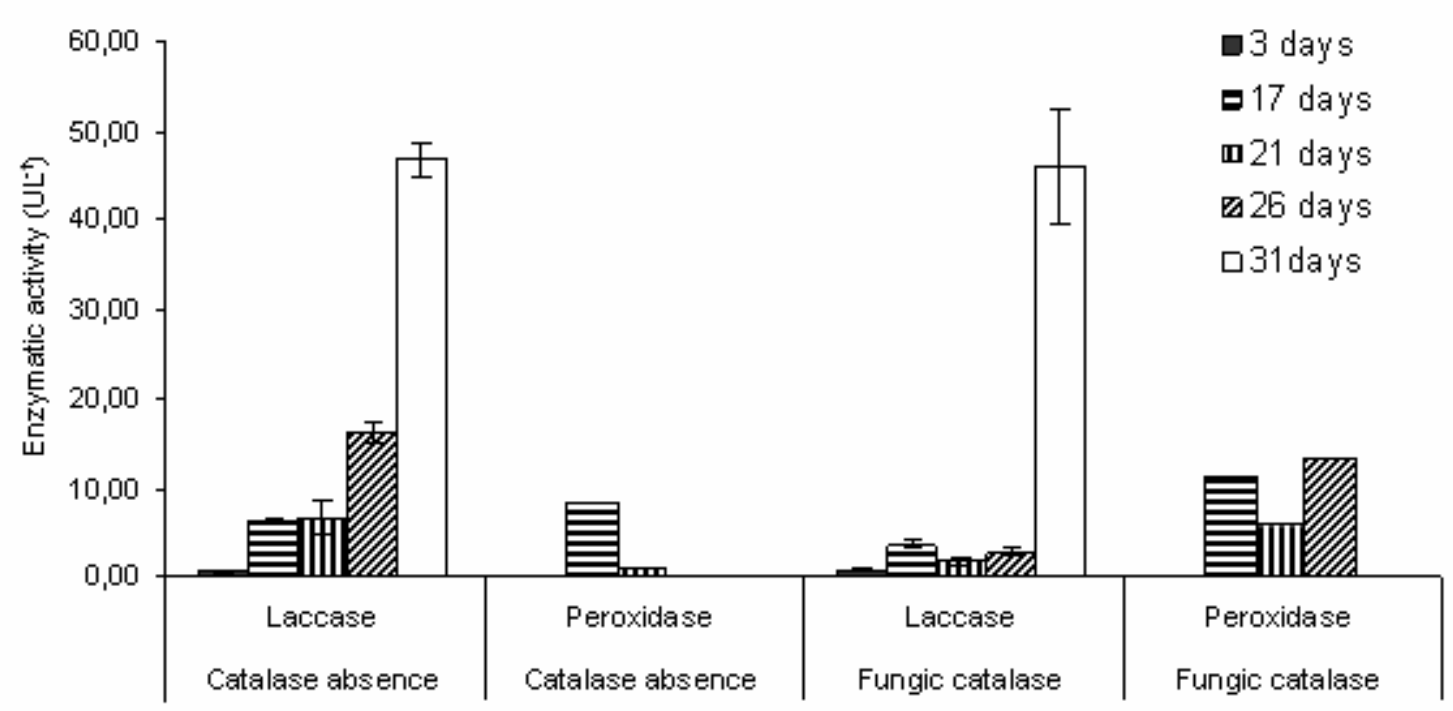

Figure 2 - Activities of laccase and peroxidases produced by Trametes villosa during growth in liquid synthetic medium determined in the absence and presence of a fungal commercial catalase preparation.

The effect of the origin of catalase preparation (fungal and bovine) was evaluated applying the enzyme on the extracts obtained from $L$. crinitus grown on solid substrate. The fungal catalase inhibited 76 and $47 \%$ of laccase activity in extracts obtained after 15 and 20 days of incubation, respectively (Fig. 3). No inhibition of laccase activity was observed in the presence of bovine catalase, making clear that laccase activity produced by basidiomycetes fungi suffered inhibition when A. niger catalase was added to the reaction. No similar studies were found in the literature about catalase preparation influence on activities assays of ligninolytic enzymes produced by basidiomycetes.
Another problem observed previously with the fungal commercial catalase preparation was the oxidation of ABTS in the absence of enzymatic basidiomycete extract at acid $\mathrm{pH}$. Oxidation of ABTS (activity of $879.7 \mathrm{U} / \mathrm{L}$ ) in the absence of basidiomycete extract was observed only when the commercial catalase preparation was incubated in citrate-phosphate buffer at $\mathrm{pH}$ 2.78. When this enzymatic assay was performed with catalase preincubated with $50 \mu \mathrm{L} 1 \mathrm{mM}$ sodium azide, $98 \%$ inhibition of activity was observed. These results suggested the presence of others enzymes as contaminants in the fungal commercial catalase preparation as described by Rescigno et al. (2007) for commercial sources of mushroom tyrosinase. 


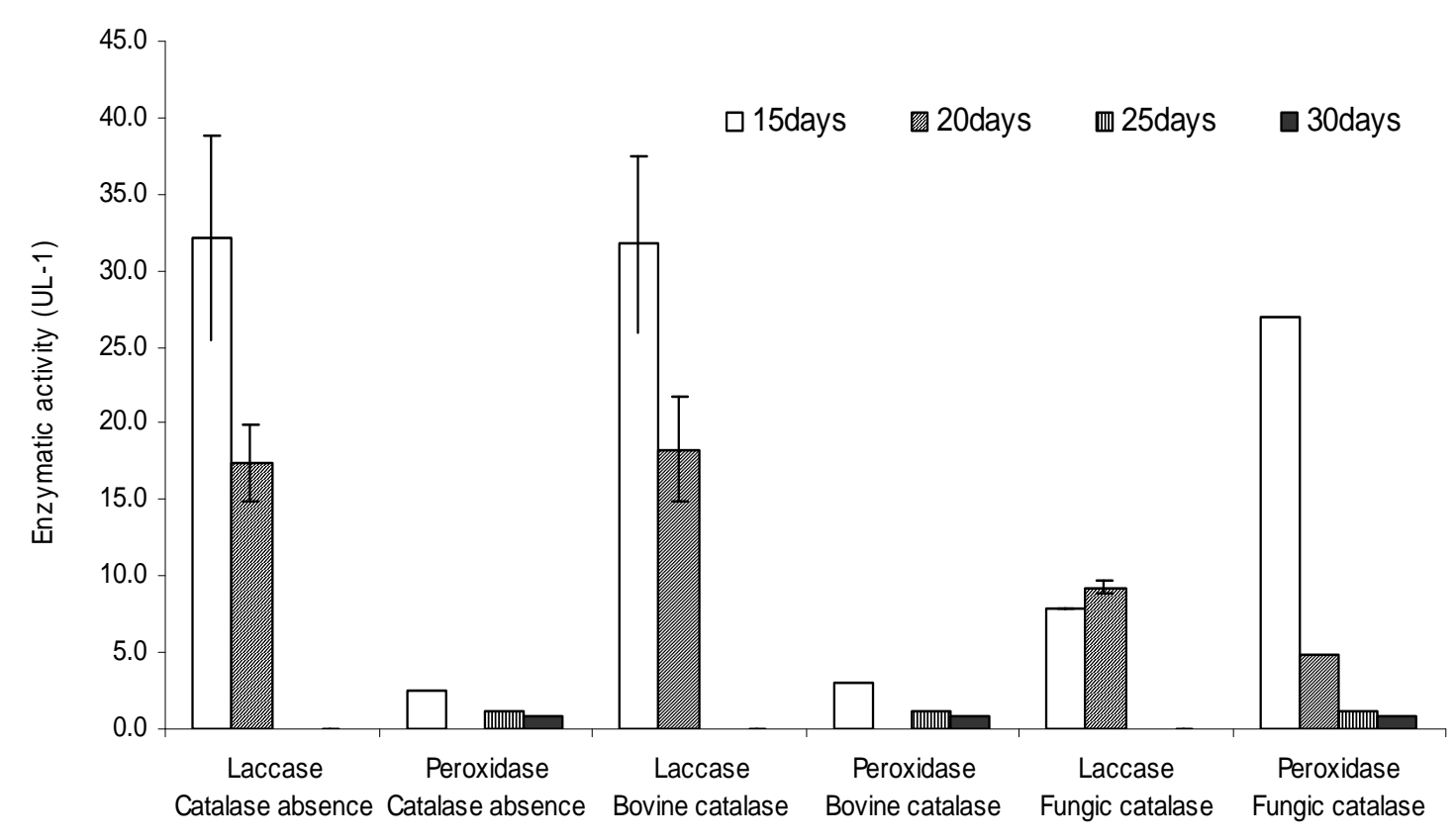

Figure 3 - Activities of laccase and peroxidases produced by Lentinus crinitus during growth on solid substrate determined in the absence and presence of a fungal or bovine commercial catalase preparation.

\section{CONCLUSIONS}

The enzymatic activity assay of the ligninolytic system of basidiomycetes was interfered by the commercial catalase preparation, underestimating laccase activity and overestimating peroxidase activity. The determination of $\mathrm{H}_{2} \mathrm{O}_{2}$ in enzymatic extracts obtained from basidiomycetes grown in liquid or solid media is necessary to indicate the need for the use of catalase in the reaction mixture.

\section{ACKNOWLEDGMENTS}

We thank FAPESP, FUNDEPAG, and Unisantos for financial support.

\section{RESUMO}

A influência da preparação comercial de catalase (origem fúngica e bovina) nos ensaios de atividade de lacase e de peroxidases foi avaliada empregando-se extratos enzimáticos obtidos do crescimento de diversos basidiomicetos em diferentes condições de cultivo. Não foi detectado $\mathrm{H}_{2} \mathrm{O}_{2}$ nos extratos. Inibição de 40 a $80 \%$ da atividade de lacase foi relacionada à fonte de catalase. Além disso, foi observada oxidação do substrato (ABTS) pela catalase fúngica, na ausência de extrato enzimático do basidiomiceto. Os resultados evidenciaram a necessidade de se proceder a uma avaliação da interferência da preparação comercial de catalase, quando o seu uso se fizer necessário na mistura reacional.

\section{REFERENCES}

Baldrian, P. (2005), Fungal laccases occurrence and properties. FEMS Microbiol Rev, 30, 215-242.

Böckle, B., Martinés, M.J., Guillén, F. and Martinés, A.T. (1999), Mechanism of peroxidase inactivation in liquid cultures of the ligninolytic fungus Pleurotus 
pulmonarius. Applied and Environmental Microbiology, 923-928.

Bonnarmet, P. and Jeffries, T. W. (1990), Mn(II) regulation of lignin peroxidases and manganesedependent peroxidases from lignin-degrading white rot fungi. Applied and Environmental Microbiology, 210-217.

Bourbonnais, R. and Paice, M.G. (1988), Veratryl alcohol oxidases from the lignin-degrading basidiomycete Pleurotus sajor-caju. Biochemical Journal, 255, 445-450.

Claus, H. (2004), Laccases: structure, reactions, distribution. Micron, 35, 93-96.

Eggert, C., Temp, U., Dean, J. F. D. and Eriksson, K. E. L. 1996. A fungal metabolite mediates degradation of non-phenolic lignin structures and synthetic lignin by laccase. FEBS Letters 391: 144-148.

Glenn, J.K. and Gold, M.H. (1983), Decolorizaztion of several polymeric dyes by the lignin-degrading basidiomycete Phanerochaete chrysosporium. Applied and Environmental Microbiology, 45 (6), 1741-1747.

Gonzalesa, L.; Hernándeza, J. R.; Peresteloa, F.; Carniceroa; A. and Falcóna,. M. A. 2002. Relationship between mineralization of synthetic lignins and the generation of hydroxyl radicals by laccase and a low molecular weight substance produced by Petriellidium fusoideum. Enzyme and Microbial Technology, 30 (4) 474-481.

Guillén, F.; Toribio, V. G.; Martínez, M. J. and Martínez, A. T. (2002), Production of Hydroxyl Radical by the Synergistic Action of Fungal Laccase and Aryl Alcohol Oxidase. Archives of Biochemistry and Biophysics, 383 (1) 142-147.

Hakala, T.K. Lundella, T. Galkina, S. Maijala, P. Kalkkinen and N. Hatakka, A. (2005), Manganese peroxidases, laccases and oxalic acid from the selective white-rot fungus Physisporinus rivulosus grown on spruce wood chips. Enzyme and Microbial Technology, 36, 461-468.

Kirk, T.K., Connors, W. and Zeikus, J.G. (1976), Requirement for a growth substrate during lignin decomposition by two wood-rotting fungi. Applied and Environmental Microbiology, 32 (1), 192-194.

Koenigs, J. W. (1972), Production of extracellular hydrogen peroxide and peroxidase by wood-rotting fungi. Phytopathology, 62, 100-110.

Kuwarara, M., Glenn, J.K. and Morgan, M.A. (1984), Separation and characterization of two extracellular $\mathrm{H}_{2} \mathrm{O}_{2}$-dependent oxidases from ligninolytic cultures of Phanerochaete chrysosporium. Febs Letters, 169, 247-250.
Lonergan, G. and Baker, W. L. 1995. Comparative study of substrates of fungal laccase. Letters in Applied Microbiology, 21 (1), 31-33.

Machado, K.M.G. and Matheus, D. R. (2006), Potential of a ligninolytic enzymatic complex produced by Pleurotus ostreatus during growth on solid substrate for the biodegradation of organic pollutants. Brazilian Journal of. Microbiology, 37: 468-473.

Mayer A.M. and Staples R.C. (2002), Laccase: new functions for an old enzyme. Phytochemical., 60 (6), 551-565(15).

Moreira, M.T.; Feijoo,G.; Mester, T.; Mayorga, P.; Sierra-Alvarez, R. and Field, J.A. (1998), Role of organic acids in the manganese-independent

biobleaching system of Bjerkandera sp. Strain BOS55. Applied and Environmental Microbiology, 24092417.

Navarro, R. E. and Aguirre, J. 1998. Posttranscriptional Control Mediates Cell Type-Specific Localization of Catalase A during Aspergillus nidulans Development. Journal of Bacteriology, 180 (21), 5733-5738.

Rescigno, A.; Zucca, P.; Flurkey, A.; Inlow, J.; Flurkey, W. H. (2007), Identification and discrimination between some contaminant enzyme activities in commercial preparations of mushroom tyrosinase. Enzyme and Microbial Technology, 41, 620-627.

Scherer, M. and Fischer, R. 2001. Molecular characterization of a blue-copper laccase, TILA, of Aspergillus nidulans. FEMS Microbiology Letters. 199 (2), 207-213.

Srinivasan, C.; D'souza, T. M.; Boominathan,K. and Reddy, C.A. (1995), Demonstration of laccase in the white rot basidiomycete Phanerochaete chrysosporium BKM-F1767. Applied and Environmental Microbiology, 4274-4277

Srebotnik E. and Boisson, J. N. (2001), Peroxidation of linoleic acid during the oxidation of phenols by fungal laccase. Physiological and Molecular Plant Pathology, 59 (5), 235-242.

Tien, M. and Kirk, T.K. (1983), Lignin-degrading enzyme from the hymenomycete Phanerochaete chrysosporium. Burds. Science, 221, 661-663.

Tonon, F. and Odier, E. (1988), Influence of veratryl alcohol and hydrogen peroxide on ligninase activity and ligninase production by Phanerochaete chrysosporium. Applied and Environmental Microbiology, 54 (2), 446-472

Received: August 10, 2006; Revised: April 02, 2007; Accepted: December 23, 2008. 